\title{
A Simple Approach to Estimate Saturated Hydraulic Conductivity
}

\author{
Ekhmaj A.I. and A.M. Abdulaziz ${ }^{1}$
}

\begin{abstract}
Saturated hydraulic conductivity is a good indicator to evaluate the hydrophysical situation of the soil. The measurement techniques used to estimate such property remain hampered by extensive labor and time constraints. Both emitter discharge rate and steady saturated radius emerged from point source trickle irrigation on the soil surface were used to determine the saturated hydraulic conductivity (basic infiltration rate) using Wooding's equation. Field experiments on sandy and sandy loam soils were conducted to estimate the saturated hydraulic conductivity based on point source trickle irrigation. The results showed that predicted saturated hydraulic conductivity values were within $23 \%$ and $26 \%$ of measured values as estimated by constant head method under laboratory condition. Additionally, the Wooding's equation was found to produce equally or more accurate descriptions of saturated hydraulic conductivity as compared to several published pedotransfer functions (PTFs) used to estimate the saturated hydraulic conductivity.
\end{abstract}

Keywords: saturated hydraulic conductivity, trickle irrigation, Pedotransfer functions .

\section{INTRODUCTION}

Saturated hydraulic conductivity (ks) is an important soil property, especially for many soil-water related investigations such as water conservation, water management and solute transport in the soil. Saturated hydraulic conductivity can be determined by field or laboratory methods, however, the measurement techniques remain expensive and time consuming. The importance of and demand for $\mathrm{K}_{\mathrm{s}}$ data motivated researches to develop indirect method of obtaining $\mathrm{K}_{\mathrm{s}}$. Pedotransfer functions (PTFS) are becoming increasingly popular for estimating saturated hydraulic conductivity from soil physical properties such as soil texture, bulk density, organic matter content, and water retention. The majority of PTFs are completely empirical, although physico-emprical models and fractal theory models have also been developed ( Sobieraj, et al., 2001).

Some physico-empirical approaches to estimate $K_{\mathrm{s}}$ have been proposed based on either geometric mean particle diameter (Campbell, 1985) or soil water retention curve parameters (Laliberte et al., 1968).

However, these methods may be more suitable for predicting near-saturated hydraulic conductivity, excluding macropore effects (Jarvis et al., 1999). Aimrun et al (2004) used a power function based on effective porosity $\varnothing_{\mathrm{e}}$ to determine saturated hydraulic conductivity for lowland paddy soils. Although the results indicated a strong relationship between $K_{s}$ and $\varnothing_{e}$ it needs to be validated versus other type of soil. Among the advantages of trickle irrigation, the information of flow rate from a point source and the respective saturated water entry radius $r_{s}$ can be used to estimate the saturated hydraulic conductivity. The size of saturated area under drippers is strongly related to the saturated hydraulic conductivity and the emitter discharge rate. Such relationships were described by Wooding 1968, Clothier et al, 1983, Shani et al, 1987. This paper present an easy method to estimate the saturated hydraulic conductivity under field condition based on simple obtainable data from point source trickle irrigation experiments. The data used for such estimation were, emitter discharge rate and the wet radius on the soil surface.

\section{Theoretical consideration}

Wooding (1968) presented an approximate solution for steady-state flow per unit area, q, from a shallow saturated entrance on the soil surface as follows:

$$
q=\frac{Q}{\pi r_{s}^{2}}=k_{s}+\frac{4 . k_{s}}{\pi \alpha} \cdot \frac{1}{r_{s}}
$$

where $\mathrm{Q}$ is discharge rate of the point source $\left(\mathrm{L}^{3} \mathrm{~T}^{-1}\right)$ , $\mathrm{k}_{\mathrm{s}}$ is the saturated hydraulic conductivity $\left(\mathrm{L} \mathrm{T} \mathrm{T}^{-1}\right), \mathrm{r}_{\mathrm{s}}$ is the steady-state saturated radius $(\mathrm{L}), \alpha$ is a constant related to soil sorptive properties and describes the reduction rate of conductivity with matric head $\left(\mathrm{L}^{-1}\right)$. The reciprocal value of $\alpha$ is a parameter quantifies the contribution of capillary forces relative to gravity forces (Philip, 1969). In order to reach this solution an exponential relation between the hydraulic conductivity and the hydraulic potential was assumed:

$$
k(h)=k_{s} \exp (\alpha h)
$$

\footnotetext{
${ }^{1}$ Department of Soil and water, Faculty of Agriculture Alfateh University, Tripoli- Libya

Received August 2, 2007, Accepted August 30, 2007
} 
According to Eq. [1] the saturated radius increases with the increasing of the application rate and with the reducing of the saturated hydraulic conductivity. In addition, the first term on the right side of Eq. [1] represents the contribution of gravity to the flow, and the second term represents the contribution of capillarity and geometry of the source. Hence, equation 1 can be arranged to be in form of linear regression equation of $q$ versus $1 / \mathrm{r}_{\mathrm{s}}$ as

$$
y=a+b x
$$

where $\mathrm{a}$ and $\mathrm{b}$ represent the intercept and the slope of the linear regression equation. So, the saturated hydraulic conductivity can be estimated from the intercept of the linear regression equation and $\alpha$ is estimated as follows:

$$
\alpha=\frac{4 . k_{s}}{b . \pi}
$$

\section{MATERIALS AND METHODS}

Field experiments were conducted on sand and sandy loam bares soil found at two locations situated $20 \mathrm{~km}$ south of Tripoli-Libya along the way to the International Tripoli Airport. The sandy soil was classified as loose, very friable, and highly drained and has very fine roots, while the sandy loam was classified as massive, moderately hard, and fine and medium irregularly shaped of lime concentrations with common fine roots. The main physical characteristics of both soils are given in the Table 1 The experimental procedures to determine these properties were determined as described by Black, et al 1965 whereas the texture of soil was determined by the pipette method the bulk density was determined using undisturbed core and the average saturated hydraulic conductivity determined on undisturbed samples using the constant head method The saturated moisture content was taken to be equal to the porosity of soil Hillel, (1982).

The apparatus of trickle irrigation system used in this investigation was designed to provide uniform water application from a point source at various rates. Essentially, the apparatus consisted of a modified Marriott tube (Yitayew and Waston, 1986) was used as a reservoir joined to emitters by means of hose 0.75 in ID. The Emitters were calibrated for the application of the required volume at desired rate. The outlets were located on the soil surface where each dripper irrigated a distinct area without any interface with others. Various application rates were chosen between 1.5 and 6 liter per hour for the sand and 1-4 1/h for the sandy loam soil. In order to evaluate the model more thoroughly, a series of pedotransfer functions (PTFs) in predicting $\mathrm{K}_{\mathrm{s}}$ were selected from published data may support the proposed model for determining the saturated hydraulic conductivity. The selected PTFs were developed by Brakensiek et al. (1984), Campbell and Shiozawa (1994), Cosby et al. (1984), Jabro (1992), Puckett et al. (1985), Dane and Puckett (1994) and Saxton et al. (1986).

Table 1. Summary of soil physical properties used in the study

\begin{tabular}{cccccccc}
\hline Soil & Sand $\%$ & Silt & Clay $\%$ & $\begin{array}{c}\text { Bulk density } \\
\mathbf{M g} / \mathbf{m}^{3}\end{array}$ & $\begin{array}{c}\text { Initial and saturated Moisture } \\
\text { content (Vol) }\end{array}$ & Ks $\mathbf{~ m / d ~}$ \\
\hline $\begin{array}{c}\text { Sand } \\
\text { Sandy }\end{array}$ & 98 & - & - & 1.58 & $0.05-0.40$ & 4.82 \\
Loam & 73 & 17 & 10 & 1.38 & $0.06-0.48$ & 1.39 \\
\hline
\end{tabular}

Table 2. Peodotransfer functions used for estimating saturated hydraulic conductivity*

\begin{tabular}{ll}
\hline \hline & $\mathrm{K}_{\mathrm{s}}(\mathrm{mm} / \mathrm{h})=\exp \left[19.52348 \varnothing-8.96847-0.028212\left(\mathrm{P}<_{2}\right)+0.00018107\left(\mathrm{P}_{50-2000}\right)^{2}-\right.$ \\
& $0.0094125\left(\mathrm{P}<_{2}\right) 2-8.839521 \phi^{2}+0.077718(\mathrm{P} 50-2000) \emptyset-0.00298\left(\mathrm{P}_{50-2000}\right)^{2} \phi^{2}-$ \\
& $0.019492\left(\mathrm{P}<_{2}\right)^{2} \phi^{2}+0.0000173\left(\mathrm{P}_{0-2000}\right)^{2}\left(\mathrm{p}<_{2}\right)+0.02733\left(\mathrm{P}<_{2}\right)^{2} \varnothing+0.001434\left(\mathrm{P}_{50-2000}\right)^{2} \varnothing-$ \\
& $\left.0.0000035\left(\mathrm{P}<_{2}\right)^{2}\left(\mathrm{P}_{50-2000}\right)\right]$ \\
2. Brakensiek et al. (1984) & $\mathrm{K}_{\mathrm{s}}(\mathrm{mm} / \mathrm{h})=54 \exp \left[-0.07 \mathrm{P}_{50-2000^{-}} 0.167 \mathrm{P}<_{2}\right]$ \\
3. Cosby et al. (1984) & $\mathrm{K}_{\mathrm{s}}(\mathrm{mm} / \mathrm{h})=25.4 \times 10(-0.6+0.012 \mathrm{P} 50-2000-0.0064 \mathrm{P}<2)$ \\
4. Jabro (1992) & $\log \left(\mathrm{K}_{\mathrm{s}}\right)(\mathrm{cm} / \mathrm{h})=9.56-0.81 \log \left(\mathrm{P}_{2-50}\right)-1.09 \log \left(\mathrm{P}_{<2}\right)-4.64(\mathrm{BD})$ \\
5. Puckett et al. (1985) & $\mathrm{K}_{\mathrm{s}}(\mathrm{mm} / \mathrm{h})=156.96 \exp \left(-0.1975 \mathrm{P}_{<2}\right)$ \\
6. Dane and Puckett (1994) & $\mathrm{K}_{\mathrm{s}}(\mathrm{mm} / \mathrm{h})=303.84 \exp \left(-0.144 \mathrm{P}_{<2}\right)$ \\
& $\mathrm{K}_{\mathrm{s}}(\mathrm{mm} / \mathrm{h})=10 \exp \left[12.012-0.0755 \mathrm{P}_{50-2000}+\left(-3.895+0.03671 \mathrm{P}_{50-2000^{-}}\right.\right.$ \\
& $\left.0.1103 \mathrm{P}_{<2}+0.00087546\left(\mathrm{P}_{<2}\right)^{2} / \theta_{\mathrm{s}}\right]$ \\
7. Saxton et al. (1986) & where $\theta_{\mathrm{s}}=0.332-0.0007251 \mathrm{P}_{50-2000}+0.1276 \log 10(\mathrm{P}<2)$ \\
\hline \hline
\end{tabular}

* Note: particle sizes in these PTF equations are listed as $\mathrm{P}<2$ (clay), P2-50(silt), and P50-2000(sand). In addition, BD= bulk density, $\varnothing=$ porosity, and $\theta_{\mathrm{s}}=$ saturated moisture content. 
The basis for choosing these PTFs was governed by the available input data i.e., particle size distribution, bulk density and saturated moisture content (Table 2). The differences between these models are more related to the input data.

These differences create advantages which could help for verification purpose. During each experiment, the movement of saturated water entry radius was recorded periodically. The experiments were replicated five times, each one with various application rates.

\section{RESULTS AND DISCUSSIONS}

Close observations indicated that the actual water source did not behave as an ideal point source, but the water was spaced over a finite circular water saturated area. The border of saturated area was determined visually as the point where the free-water indicated by glistening surface zone ended on the soil surface. It was also noted that the saturated zone various according to discharge rate. Figure.1 displays the final saturated radius versus emitter discharge rate for sandy and sandy loam soil. For sandy soil the steady radius values were achieved after about 25 minutes. It is clear from the figure that the saturated radius increased as the discharge rate increased where the maximum value of the saturated radius $7 \mathrm{~cm}$ was found under application rate of $61 / \mathrm{h}$. In case of sandy loam soil, the steady value of the saturated radius reached about 30 minutes. The

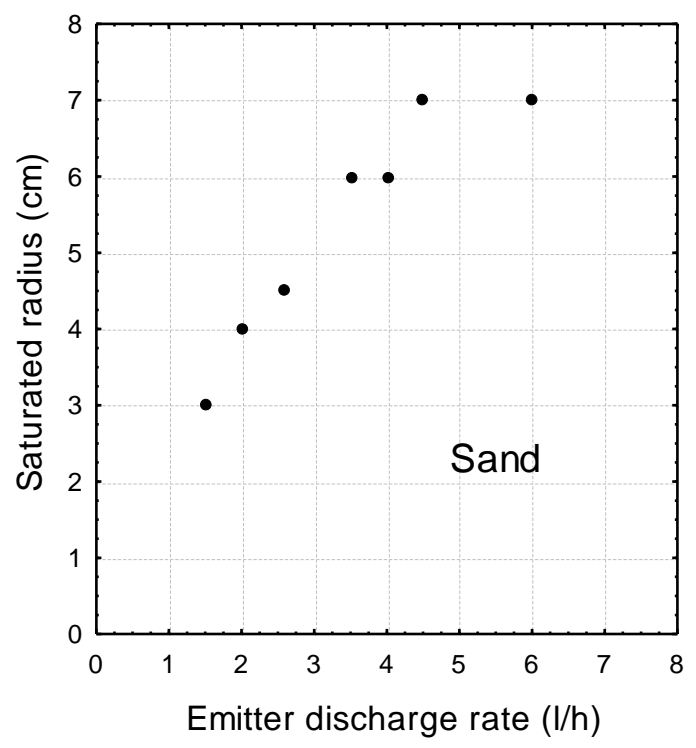

maximum values of saturated radius ranged from 4 to 9 $\mathrm{cm}$. However, many studies assured that the rate of increase and limiting extent of the central saturated radius is a function of soil type and application rate (Clothier et al, 1983, Shani et al, 1987, Yitayew et al., 1998).

Figure. 2 depicts the relationship of flux densities, q, versus the reciprocal of steady state radii $1 / \mathrm{r}_{\mathrm{s}}$, produced by the point source for sandy and sandy loam soil, respectively. It can be noted, as expected, the saturated hydraulic conductivity $\mathrm{k}_{\mathrm{s}}$ (the intercept) and the values of $\alpha$ increased as the soil texture is coarser. These results agree with what reported by Amoozegar-Fard et al 1984. The values of $k_{\mathrm{s}}$ and $\alpha$ are displayed in Figure 2 .

The determination coefficient of the linear regression describing the relation between $\mathrm{q}$ and $1 / \mathrm{r}$ are relatively good 0.72 and 0.75 for sandy and sandy loam, respectively. There is good agreement between $\mathrm{k}_{\mathrm{s}}$ values as produced by the point source method and that produced by constant head method (differences of $26 \%$ and $23 \%$ for sandy and sandy loam, respectively). The discrepancies might be attributed to the impact of surface topography where there was no guarantee that point source infiltration area would be exactly circular. Moreover, a wide range of discharge rates can be useful and help to minimize error in estimation of saturated hydraulic conductivity.

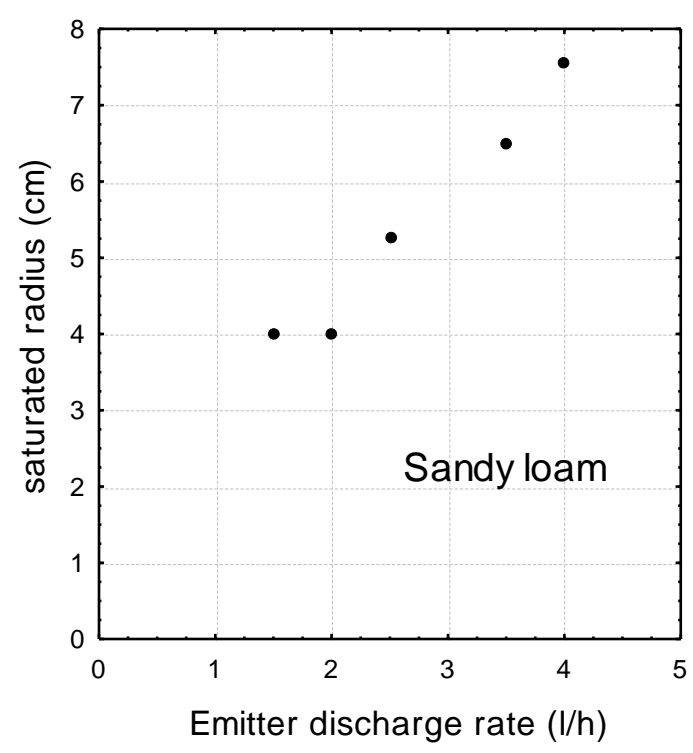

\section{Figure 1. the final saturated radius as related to the emitter discharge rate}



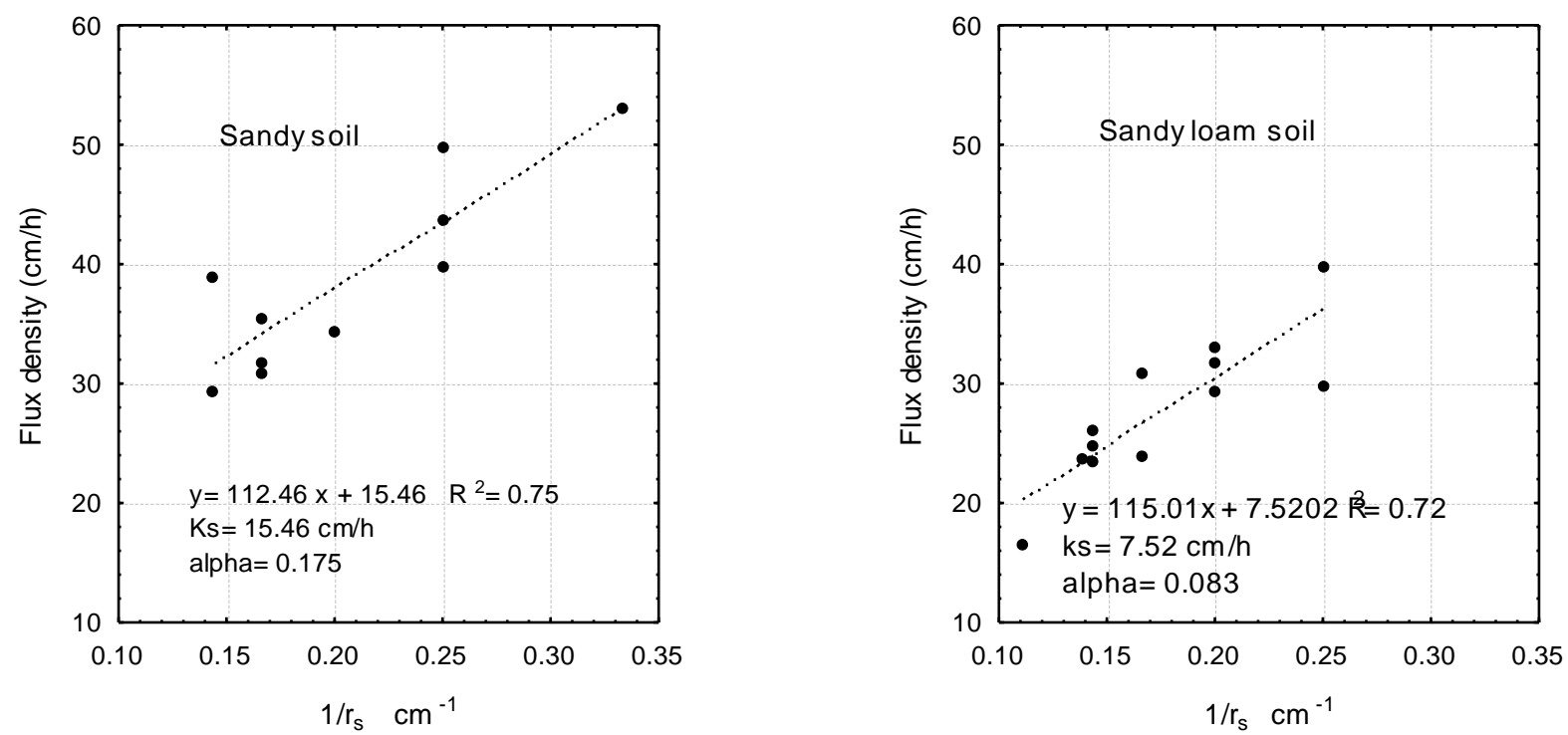

Figure 2. the relationship of flux densities, $q$, versus the reciprocal of steady-state radii, $1 / r_{\mathrm{s}}$ for sandy and sandy loam soil.

\section{Comparison with PTFs}

Table (3) shows the values of $\mathrm{K}_{\mathrm{s}}$ for sandy and sandy loam soils as estimated, by constant head method, Wooding's equation and pedotransfer functions (PTFs). The saturated hydraulic conductivity as measured by head method was chosen for comparison purpose. Among PTFs models, one sees that Saxton, Dane and Cosby functions give a high accuracy to predict the saturated hydraulic conductivity. This suggests that the values of saturated moisture content and the percentage of sand, silt and clay can be use to determine $\mathrm{K}_{\mathrm{s}}$. On the other hand, it can be noted from the figure (3) that the discrepancies between measured and simulated saturated hydraulic conductivity is generally smaller with Wooding's equation as compared to the most PTFs findings.

\section{CONCLUSION}

The aim of this paper has been to examine how the point source trickle irrigation can help to estimate the saturated hydraulic conductivity. A simple method based on Wooding (1968) equation was used to estimate the saturated hydraulic conductivity. The results showed that the trickle application rate controls the saturated radius on the soil surface. The saturated radius reaches steady values in sandy soil faster than sandy loam soil. The saturated hydraulic conductivity as predicted by 1 for steady- state infiltration from circular ponded area matched with the measured values (23-26\% variation).

Moreover, the Wooding's equation was found to produce equally or more accurate descriptions of saturated hydraulic conductivity as compared to several published pedotransfer functions (PTFs) used to estimate the saturated hydraulic conductivity. It is interesting to assure that the Wooding method is simple and suitable for determining the saturated hydraulic conductivity where no sophisticated instruments are required, only multiple emitters (at different rates), reservoir with enough capacity, a ruler for measuring distance, a timer and calibrated container to calibrate emitter discharge rate. This method also is not destructive so it can be adapted to measuring changes in soil hydraulic properties with time at the same sampling site. Further more, labor and operating cost are lower. A wide range of discharge rates may useful and helps to minimize error in estimation of saturated hydraulic conductivity.

Table 3. observed and predicted saturated hydraulic conductivity, $\mathrm{ks}(\mathrm{cm} / \mathrm{h})$ for sand and sandy loam soil

\begin{tabular}{ccc}
\hline \hline Method & Sandy soil & Sandy loam soil \\
\hline Braken & 52.26 & 15.46 \\
Campbell & 0.0047 & 0.006 \\
Jabro & 15.8 & 11.74 \\
Puckett & 12.88 & 2.177 \\
Dane & 26.30 & 7.198 \\
Saxton & 21.19 & 4.88 \\
Cosby & 14.46 & 5.38 \\
Constant head & 20.08 & 5.79 \\
method & & 7.52 \\
Wooding & 15.46 & \\
\hline \hline
\end{tabular}




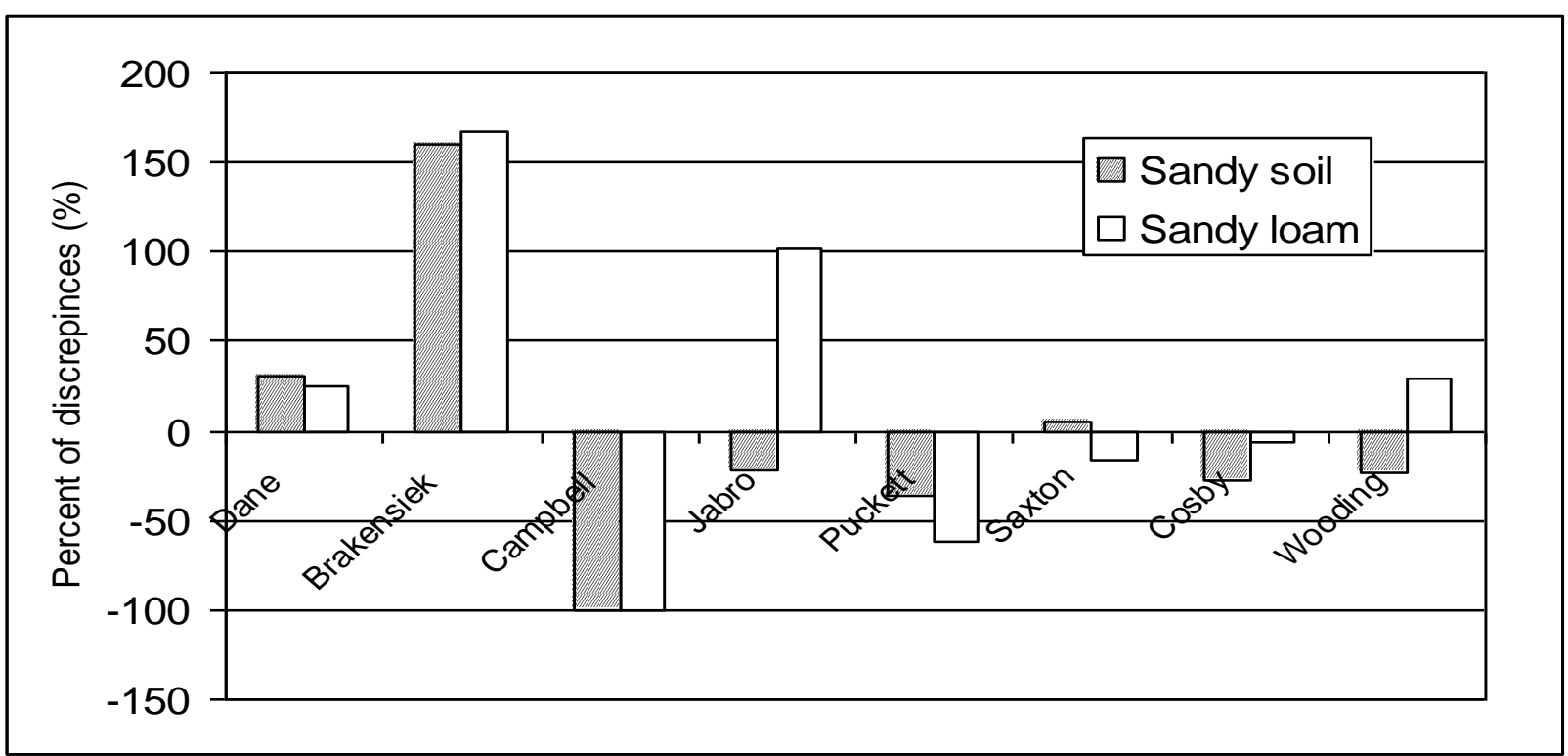

Figure 3. The discrepancies ( in percent) between the several predicted methods (as compared to the constant head method) for predicting saturated hydraulic conductivity for sand and sandy loam soil

\section{REFERENCES}

Aimrun W., MSN Amin and SM Eltaib. 2004. Effective Porosity of Paddy Soils as an Estimation of its Saturated Hydraulic Conductivity. Geoderma 121 (2004) 197-203.

Amoozegar-Fard, A., A.W. Warrick, and D. O. Lomen. 1984. Design nomographs for trickle and subsraface irrigation. Journal of Irrigation and Drainage Engineering. 110(2):107-120.

Black, C.A., D.D. evans. J. W. White, L. E. Ensminger and F. E. Clark. 1965. Methods of soil analysis part I. Agronomy No. 9 American Society of Agronomy, Madison. Wis. USA.

Brakensiek,D.L., Rawls, W. J., Stephenson, G.R., 1984. Modifying SCS hydrologic soil groups and curve numbers for rangeland soils. ASAE paper no. PNR-84203, St.Joseph, MI.

Campbell, G.S., 1985. Soil Physics with Basic. Transport Models for Soil-Plant Systems. Developments in Soil Science, vol. 14. Elsevier, Amsterdam.

Campbell, G.S., Shiozawa, S., 1994. Prediction of hydraulic properties of soils using partice-size distribution and bulk density data. In : van Genuchten, M. Th., et al.(Eds.)Proceedings of the international Workshop on Indirect Methods for Estimating the Hydraulic Properties of Unsaturated Soils. University of California, Riverside, CA, pp. 317-328.

Clothier B. E. and R. A. Wooding. 1983 The soil water diffusivity near saturation. Soil. Sci. Soc. Am. J 47:363640.
Cosby, B. J., Homberger, G. M., Clapp, R. B., Ginn, T. R., 1984. A statistical exploration of soil water retention characteristics. Water Resour. Res. 20, 682-690.

Dane, J. H., puckett, W., 1994. Field soil hydraulic properties based on physical and mineralogical information. . In : van Genuchten, M. Th., et al.(Eds.) Proceedings of the international Workshop on Indirect Methods for Estimating the Hydraulic Properties of Unsaturated Soils. University of California, Riverside, CA, pp. 389-403.

Hillel, D. 1982, Introduction to Soil Physics. Academic Press, New York Chapters 1-7. pp 1-134.

Jabro, J. D., 1992. estimation of saturated hydraulic conductivity of soils from particle size distribution and bulk density data. Trans. ASAE 35 (2). 557-560.

Jarvis, N.J., Messing, I., Larsson, M.H., Zavattaro, L., 1999. Measurement and prediction of near-saturatedhydraulic conductivity for use in dual-porosity models. In: van Genuchten, M.T., Leij, F.J., Wu, L. (Eds.), Characterization and Measurement of the Hydraulic Properties of Unsaturated Porous Media, pp. 839- 850, US Salinity Lab. USDA-ARS, Riverside, CA, USA.

Lalibert, G. E., Brooks, R.H. e Corey, A.T., 1968. Permeability calculated from the saturation data. Journ. Irrig. Drainage Div., Proc. ASCE, 94, 57-69.

Philip, J.R. 1969. Theory of infiltration. Adv. Hydrosci. 5:215-296.

Puckett, W.E., Dane, J. H., Hajek, B. F., 1985. Physical and mineralogical data to determine soil hydraulic properties. Soil Sci. Soc. Am. J. 49, 831-836. 
Saxton, K.E., Rawls, W.J., romberger, J.S., Pepndick, R.I., 1986. Estimating generalized soil water characteristics from soil texture. Soil Sci. Soc.Am. J. 55, 1231-1238.

Shani, U., R.J. Hanks, E. Bresler, and C.A.S. Oliveria. 1987. Field method of estimating hydraulic conductivity and matric potential-water content relations. Soil Sci. Soc. Am. J. 51:298-302.

Wooding, R.A. 1968. Steady infiltration from a drip source, Water Resource Research 4:1259-1273.
Yitayew M.,Khan A. A., Warrick A.W. 1998. In situ measurements of soil hydraulic conductivity using point application of water Applied engineering in Agriculture, 14(2):115-120.

Yitayew, M. and J.Waston. (1986). Field methods for determining unsaturated hydraulic conductivity ASAE paper No.86-2570.St.josph, Mich: ASAE. 


\section{الملخص العربي}

\section{طريقة مبسطة لحساب التوصيل الهيدروليكى المثبع}

$$
\text { احمد ابراهيم اخماج وعبدالززاق مصباح عبدالعزيز }
$$

وقد اوضحت النتائج ان قيم التوصيل الهيدروليكى المشبع المتنبـا بها كانت في حدود 23\% و 26\% من القيم المقاسة في المعمل بطريقة

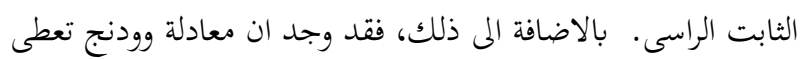
نتائج مساوية اواكثر دقة في وصف التوصيل الهيدروليكى المشبع وذلك بمقارنتها بالنتائج المنشورة والمحسوبة من دوال الانتقال الارضى.
يعتبر التوصسيل الهيـدروليكى المشـبع مـن خـواص التربـة اللازمـة

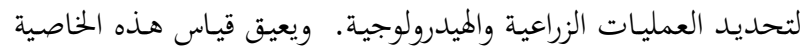

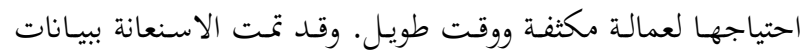

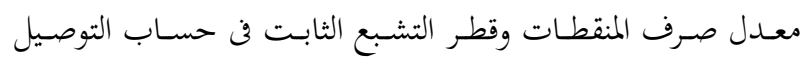

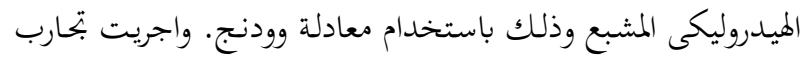

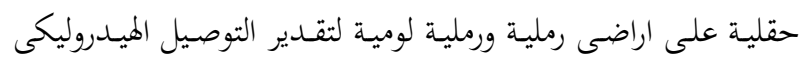
المشبع تحت ظروف الرى بالتنقيط. 